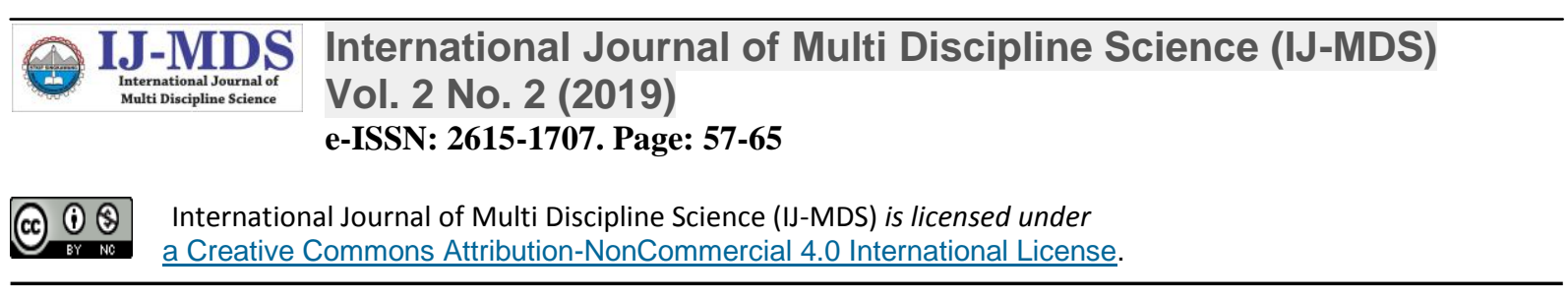

\title{
Description of Students Thinking on Warshall-Floyd Algorithm
}

\section{Zaini}

\section{Sekolah Tinggi Teknologi Bontang, Bontang, Indonesia zaini.math@gmail.com}

\begin{tabular}{|c|c|}
\hline Keywords: & ABSTRACT \\
\hline $\begin{array}{l}\text { Thinking, Floyd Algorithm- } \\
\text { Warshall, } \\
\text { Minimum Path }\end{array}$ & $\begin{array}{l}\text { The shortest path continues to be a trend until now that is } \\
\text { always discussed and developed. This study focuses on the } \\
\text { construction process and description of the students } \\
\text { understanding in deciding the shortest route based on the } \\
\text { matrix iteration according to the Floyd-Warshall algorithm. } \\
\text { The research approach used is descriptive qualitative research } \\
\text { and the data collection technique is a test technique. The } \\
\text { research data included problem-solving by four students with } \\
\text { different abilities and the result data were analyzed } \\
\text { inductively. The results showed that the matrix iteration with } \\
\text { the formula for determining the entry of the iteration matrix } x_{n} \\
\left.=\text { minimum( } d_{i j k-1} \text {, dikk-1 }+d_{k j k-1}\right) \text { was followed without any } \\
\text { constraints by all students until the } 7 \text { th iteration. It was found } \\
\text { that the inaccuracy of taking entries in the 1st iteration by } \\
\text { students with low ability caused calculation errors and failure } \\
\text { in finding the shortest route. }\end{array}$ \\
\hline
\end{tabular}

\section{INTRODUCTION}

The millennial generation and with the support of the available information system make it easy for them to access the information is needed. Google Maps is here to provide solutions that provide place information, the fastest travel route (shortest route) with time-space, and distance is traveled. An example of search results from Bontang College of Technology to Bontang Al-Hikmah Mosque is using Google Maps is shown in Fig 1.

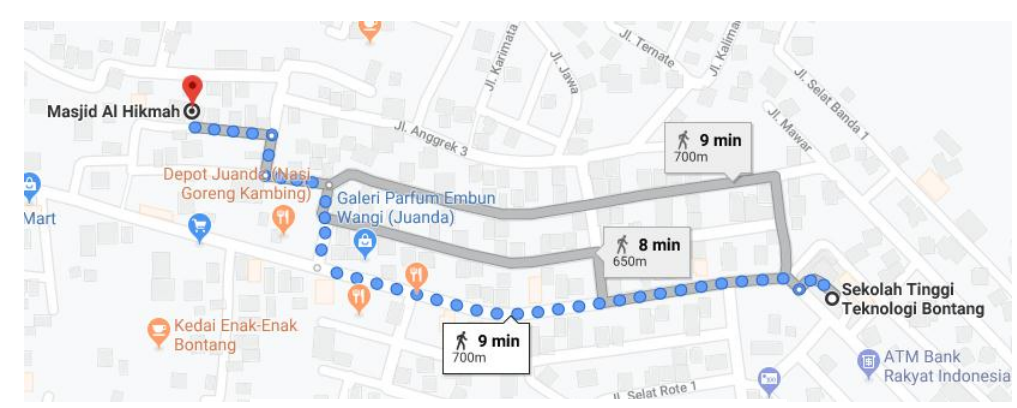

Fig 1. Place information and route

The shortest route used on Google Maps is an implementation form of mathematic material about graphs. Determination of the shortest route in the graph can use a variety of solutions including the 
Dijkstra algorithm, the Warshall-Floyd algorithm, the Bellman Ford algorithm, the Gready algorithm, the Depth First Search Algorithm (DFS), the Prim's Algorithms and Cruscal, and others. The algorithm that is the focus of research is Warshall -Floyd because it can present the shortest path length from all points to all other points (Novandi, 2007; Kriswanto, Bendi and Aliyanto, 2014; Husni et al., 2017), recovery time is superior in determining new pathways by the controller (Attamimi, Yahya and Hanfi, 2017), usage of memory is greater at an exclusive and economic level (Dermawan, 2018), and one of the variants of dynamic programming (Ramadiani et al., 2018).

The shortest path determination path in the Warshall- Floyd algorithm uses a point connectedness matrix as its prefix and then iterates as much as $\mathrm{k}=\mathrm{n}-1$. The iteration will produce an iteration matrix with the notation $X^{n}$ or $D(n)$. The entries in the iteration matrix follow the rule that the notation $d_{i j k}$ means the shortest path from $\mathrm{i}$ to $\mathrm{j}$, which also passes through vertex $\mathrm{k}$. If there exists an edge between vertices $i$ and it will be equal to $\mathrm{d}_{\mathrm{ij} 0}$, otherwise it can be assigned as infinity. However, for other values of $\mathrm{d}_{\mathrm{ijk}}$ there can be two choices:

1. If the shortest path from $i$ to $j$ does not pass through the vertex $k$ then the value of $d_{i j k}$ will be equal to $\mathrm{d}_{\mathrm{ijk}-1}$.

2. If the shortest path from $\mathrm{i}$ to $\mathrm{j}$ passes through the vertex $\mathrm{k}$ then first it goes from $\mathrm{i}$ to $\mathrm{k}$, after that goes from $k$ to $j$. In this case, the value of $d_{i j k}$ will be equal to $d_{i k k-1}+d_{k i k-1}$. Value for $d_{i j k}$ is minimum on $\mathrm{d}_{\mathrm{ijk}-1}$ and $\mathrm{d}_{\mathrm{ikk}-1}+\mathrm{d}_{\mathrm{kjk}-1}$ (Magzhan and Jani, 2013) or other writing form for presenting $\mathrm{d}_{\mathrm{ij}}$ is $\mathrm{d}_{\mathrm{ij}}=\min \left\{\left(\mathrm{d}_{\mathrm{ij}}\right)^{\mathrm{k}-1},\left(\mathrm{~d}_{\mathrm{ip}}\right)^{\mathrm{k}-1}+\left(\mathrm{d}_{\mathrm{pj}}\right)^{\mathrm{k}-1}\right\}$ (Ramadiani et al., 2018).

Workflows on the Warshall-Floyd algorithm have been tested using programs such as Latex (Husni et al., 2017) and implemented in daily life such as routes to tourism place (Marlina, 2017). Meanwhile, the limited in-depth study of knowledge construction and understanding of students' understanding in utilizing the algorithm in terms of their degree of ability. Therefore, a description of the ability of students to construct the shortest route using the Warshall-Floyd algorithm becomes the main focus of this research.

\section{METHOD}

This studying uses a descriptive qualitative research approach with a sample of research involving four students namely 1 high ability student (MF), 2 medium ability students (NY \& NM), and 1 low ability student (SS). In collecting the required data, the technique used is a test technique. The results of the problem-solving data from the four students were then analyzed inductively with three stages, namely data reduction, data presentation, and verification. They are given one math problem and during the completion of their assignment, they are kept closed. To facilitate students to iterate according to the algorithm flow, so the lecturer places himself as an advisor, consultant (Mills and Treagust, 2003) and facilitator (Felipe, Pham, and Amouroux, 2017). Through this engagement, students are expected to have a working picture, understanding concepts, and procedures following the Floyd-Warshall algorithm. To maintain the originality of their thinking, the lecturer gives an example of the matrix iteration process and then gives them freedom in constructing their knowledge to the finish. In other words, there is no objection to the process that they do so that it leads to the right path.

\section{RESULTS AND DISCUSSIONS}

Graph form as visualization of their mathematic task like Fig 2. From this visualization, each student has a mastery of concepts. They did not seem to find any obstacles that inhibit the process of thinking. They can show points to represent places and access roads through lines with weighting. This is following the definition of the graph as a set of points and lines (Yao, Yin, Zhou, and Wu, 2016). 


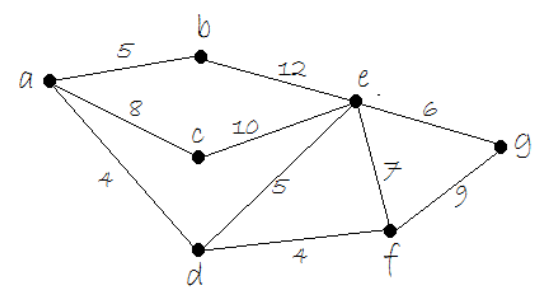

Fig 2. Presentation in graph form

The first stage carried out by the four students after they had determined graph visualization was to identify the adjacency matrix. The identification results show all students can go through well. The symbol used to express two unconnected points is " $\infty$ " and if connected, write the weight of the line with the appropriate numeric (Ramadiani., Bukhori, Azainil, and Dengen, 2018). Students use the symbol $\mathrm{D}(0)$ to express the connectedness matrix.

$$
\mathrm{D}(0)=\left(\begin{array}{ccccccc}
0 & 5 & 8 & 4 & \infty & \infty & \infty \\
5 & 0 & \infty & \infty & 12 & \infty & \infty \\
8 & \infty & 0 & \infty & 10 & \infty & \infty \\
4 & \infty & \infty & 0 & 5 & 4 & \infty \\
\infty & 12 & 10 & 5 & 0 & 7 & 6 \\
\infty & \infty & \infty & 4 & 7 & 0 & 9 \\
\infty & \infty & \infty & \infty & 6 & 9 & 0
\end{array}\right)
$$

From matrix $\mathrm{D}(0)$ then they identificate iteration matrix $\mathrm{D}(1), \mathrm{D}(2), \ldots, \mathrm{D}(7)$. The iteration matrix entry search formula used by students according to the algorithm is the value of $j \mathrm{k}=$ minimum $\mathrm{d}_{\mathrm{ijk}}=$ $\operatorname{minimum}\left(\mathrm{d}_{\mathrm{ikk}-1}, \mathrm{~d}_{\mathrm{ikk}-1}+\mathrm{d}_{\mathrm{kjk}-1}\right)$ (Magzhan and Jani, 2013) or $\mathrm{d}_{\mathrm{ij}}=\min \left\{\left(\mathrm{d}_{\mathrm{ij}}\right)^{\mathrm{k}-1},\left(\mathrm{~d}_{\mathrm{ip}}\right)^{\mathrm{k}-1}+\left(\mathrm{d}_{\mathrm{pj}}\right)^{\mathrm{k}-1}\right\}$ (Ramadiani et al., 2018).

\section{Iteration 1: $1^{\text {st }}$ row $1^{\text {st }}$ column}

The 1st iteration is a search for matrix $\mathrm{D}(1)$ derived from iteration $\mathrm{D}(0)$ and uses the value $\mathrm{k}=1$. All students identify 30 matrix entries $\left(\mathrm{d}_{\mathrm{ijk}}\right)$ They formulate each dijk with $\mathrm{x}_{1}, \mathrm{x}_{2}, \ldots, \mathrm{x}_{30}$.

$$
\mathrm{D}(1)=\left(\begin{array}{ccccccc}
0 & 0 & x_{1} & x_{2} & x_{3} & x_{4} & x_{5} \\
1 & x_{6} & 0 & x_{7} & x_{8} & x_{9} & x_{10} \\
4 & x_{11} & x_{12} & 0 & x_{13} & x_{14} & x_{15} \\
1 & x_{16} & x_{17} & x_{18} & 0 & x_{19} & x_{20} \\
1 & x_{21} & x_{22} & x_{23} & x_{24} & 0 & x_{25} \\
1 & x_{26} & x_{27} & x_{28} & x_{29} & x_{30} & 0
\end{array}\right)
$$

Look for the value $x_{1}, x_{2}, \ldots, x_{30}$ by them by observing the location of the matrix entry as a prefix which then performs a search using the formula. They state that $\mathrm{x} 1$ lies in the $2 \mathrm{nd}$ row of the $3 \mathrm{rd}$ column so that the value $x_{1}=\min \left(\mathrm{a}_{23}, \mathrm{a}_{2 \mathrm{k}}+\mathrm{a}_{\mathrm{k} 3}\right)=\min \left(\mathrm{a}_{23}, \mathrm{a}_{21}+\mathrm{a}_{13}\right)=\min (\infty, 5+8)=13$. The principle of searching for $x_{2}, \ldots, x_{30}$ follow the procedure as in $x_{1}$ pay attention to where the matrix entries are and use $\mathrm{k}=1$. From this principle they write $x_{2}=\min \left(\mathrm{a}_{24}, \mathrm{a}_{2 \mathrm{k}}+\mathrm{a}_{\mathrm{k} 4}\right)=\min \left(\mathrm{a}_{24}, \mathrm{a}_{21}+\mathrm{a}_{14}\right)=$ $\min (\infty, 5+4)=9$, and so on. The results of identification $\mathrm{D}(1)$ by students are stated in Table 1 .

The search by all students was following the procedure but still found some calculation errors. Calculation errors are experienced by SS for values $x_{3}, x_{8}$, dan $x_{9}$. The reason is none other than the inaccuracy in taking entries in the matrix $\mathrm{D}(0)$ when outlining the value of $x$ in question. 
Table 1

Comparison of Value Identification Result D(1)

\begin{tabular}{cc}
\hline $\begin{array}{c}\text { Identification result D(1) by MF, NY } \\
\text { \& NM }\end{array}$ & Identification result D(1) by SS \\
\hline $\mathrm{D}(1)=\left(\begin{array}{ccccccc}0 & 5 & 8 & 4 & \infty & \infty & \infty \\
5 & 0 & 13 & 9 & 12 & \infty & \infty \\
8 & 13 & 0 & 12 & 10 & \infty & \infty \\
4 & 9 & 12 & 0 & 5 & 4 & \infty \\
\infty & 12 & 10 & 5 & 0 & 7 & 6 \\
\infty & \infty & \infty & 4 & 7 & 0 & 9 \\
\infty & \infty & \infty & \infty & 6 & 9 & 0\end{array}\right) \quad \quad \mathrm{D}(1)=\left(\begin{array}{ccccccc}0 & 5 & 8 & 4 & \infty & \infty & \infty \\
5 & 0 & 13 & 9 & \infty & \infty & \infty \\
8 & 13 & 0 & 12 & \infty & 9 & \infty \\
4 & 9 & 12 & 0 & 5 & 4 & \infty \\
\infty & 12 & 10 & 5 & 0 & 7 & 6 \\
\infty & \infty & \infty & 4 & 7 & 0 & 9 \\
\infty & \infty & \infty & \infty & 6 & 9 & 0\end{array}\right)$ \\
\hline
\end{tabular}

\section{Iteration 2: $2^{\text {nd }}$ row $2^{\text {nd }}$ column}

Iteration 2 is the displacement of one level above the rows and columns of the $1^{\text {st }}$ iteration. The iteration 2 matrix is notated by students with $\mathrm{D}(2)$ and uses the value $\mathrm{k}=2$ to search for iteration matrix entries. searching for iteration matrix entries $\mathrm{D}(2)$ by students still use $x_{1}, x_{2}, \ldots, x_{30}$.

$$
\mathrm{D}(2)=\left(\begin{array}{c:cccccc}
0 & 5 & x_{1} & x_{2} & x_{3} & x_{4} & x_{5} \\
\hdashline 5 & 0 & 13 & 9 & 12 & \infty & \infty \\
\hdashline x_{6} & 13 & 0 & x_{7} & x_{8} & x_{9} & x_{10} \\
x_{11} & 9 & x_{12} & 0 & x_{13} & x_{14} & x_{15} \\
x_{16} & 12 & x_{17} & x_{18} & 0 & x_{19} & x_{20} \\
x_{21} & \infty & x_{22} & x_{23} & x_{24} & 0 & x_{25} \\
x_{26} & \infty & x_{27} & x_{28} & x_{29} & x_{30} & 0
\end{array}\right)
$$

Investigation the value $x_{1}, x_{2}, \ldots, x_{30}$ also remain the same as in the 1 st iteration, which is paying attention to the location of the matrix entries for each $\mathrm{x}$ in $\mathrm{D}(2)$, the difference is only in the $\mathrm{k}$ value used, namely $\mathrm{k}=2$. The search form made by them for the entry in $\mathrm{D}(2)$ is the value $\mathrm{x}_{1}=\min \left(\mathrm{a}_{13}, \mathrm{a}_{1 \mathrm{k}}+\right.$ $\left.\mathrm{a}_{\mathrm{k} 3}\right)=\min \left(\mathrm{a}_{13}, \mathrm{a}_{12}+\mathrm{a}_{23}\right)=\min (8,5+13)=8, \mathrm{x}_{13}=\min \left(\mathrm{a}_{45}, \mathrm{a}_{4 \mathrm{k}}+\mathrm{a}_{\mathrm{k} 5}\right)=\min \left(\mathrm{a}_{45}, \mathrm{a}_{42}+\mathrm{a}_{25}\right)=\min (5,9+$ $12)=5$, and so on. Overall student search results are given in Table 2 .

Table 2

Comparison of the Value Identification Result D(2)

\begin{tabular}{c} 
Identification result D(2) by MF, NY \\
\hline $\mathrm{D}(2)=\left(\begin{array}{ccccccc}0 & 5 & 8 & 4 & 17 & \infty & \infty \\
5 & 0 & 13 & 9 & 12 & \infty & \infty \\
8 & 13 & 0 & 12 & 10 & \infty & \infty \\
4 & 9 & 12 & 0 & 5 & 4 & \infty \\
17 & 12 & 10 & 5 & 0 & 7 & 6 \\
\infty & \infty & \infty & 4 & 7 & 0 & 9 \\
\infty & \infty & \infty & \infty & 6 & 9 & 0\end{array}\right) \quad \quad \mathrm{D}(2)=\left(\begin{array}{cccccccc}0 \\
5 & 0 & \infty & \infty & 12 & \infty & \infty \\
8 & \infty & 0 & 12 & 10 & \infty & \infty \\
4 & \infty & 16 & 0 & 5 & 4 & \infty \\
\infty & \infty & 12 & 5 & 0 & 7 & 6 \\
\infty & \infty & \infty & 4 & 7 & 0 & 9 \\
\infty & \infty & \infty & \infty & 6 & 9 & 0\end{array}\right)$ \\
\hline
\end{tabular}

Result of matrix iteration from $\mathrm{D}(1)$ to $\mathrm{D}(2)$ by SS are still at the same error that is the error in the selection of entries in the matrix $\mathrm{D}(1)$. The $\mathrm{x} 3$ value described by SS is in the condition that $\mathrm{x}_{3}=\mathrm{x}_{16}=$ $(\infty, 0+\infty)=\infty$. 


\section{Iteration 3: $3^{\text {rd }}$ row $3^{\text {rd }}$ column}

Iteration 3 is a one-level transfer from the $2^{\text {nd }}$ iteration. This $3^{\text {rd }}$ iteration matrix is notated $D(3)$ with a value of $k=3$. The results of identification made by students in this section are a repetition of the procedures of the previous iterations, namely the use of rows and columns.

$$
\mathrm{D}(3)=\left(\begin{array}{cc:ccccc}
0 & x_{1} & 8 & x_{2} & x_{3} & x_{4} & x_{5} \\
x_{6} & 0 & 13 & x_{7} & x_{8} & x_{9} & x_{10} \\
\hdashline 8 & 13 & 0 & 12 & 10 & \infty & \infty \\
\hdashline x_{11} & x_{12} & 12 & 0 & x_{13} & x_{14} & x_{15} \\
x_{16} & x_{17} & 10 & x_{18} & 0 & x_{19} & x_{20} \\
x_{21} & x_{22} & \infty & x_{23} & x_{24} & 0 & x_{25} \\
x_{26} & x_{27} & \infty & x_{28} & x_{29} & x_{30} & 0
\end{array}\right)
$$

Getting each value $x$, they use $x_{\mathrm{n}}=\min \left(\mathrm{a}_{\mathrm{ij}}, \mathrm{a}_{\mathrm{ik}}+\mathrm{a}_{\mathrm{kj}}\right)$ where $\mathrm{k}=3$. The calculation they make is $\mathrm{x}_{1}=$ $\min \left(\mathrm{a}_{12}, \mathrm{a}_{13}+\mathrm{a}_{32}\right)=\min (5,8+13)=5, \mathrm{x}_{2}=\min \left(\mathrm{a}_{14}, \mathrm{a}_{13}+\mathrm{a}_{34}\right)=\min (4,8+12)=4$., and so on. The overall results of $\mathrm{D}(3)$ are shown in Table 3.

Table 3

Comparison of the Value Identification Result D(3)

\begin{tabular}{c} 
Identification result D(3) by MF, NY \\
\& NM \\
\hline $\mathrm{D}(3)=\left(\begin{array}{ccccccc}0 & 5 & 8 & 4 & 17 & \infty & \infty \\
5 & 0 & 13 & 9 & 12 & \infty & \infty \\
8 & 13 & 0 & 12 & 10 & \infty & \infty \\
4 & 9 & 12 & 0 & 5 & 4 & \infty \\
17 & 12 & 10 & 5 & 0 & 7 & 6 \\
\infty & \infty & \infty & 4 & 7 & 0 & 9 \\
\infty & \infty & \infty & \infty & 6 & 9 & 0\end{array}\right) \quad \mathrm{D}(3)=\left(\begin{array}{ccccccc}0 & 5 & 8 & 4 & \infty & \infty & \infty \\
5 & 0 & \infty & 9 & 12 & \infty & \infty \\
8 & \infty & 0 & \infty & 10 & \infty & \infty \\
4 & 9 & \infty & 0 & 5 & 4 & \infty \\
\infty & 12 & 10 & 5 & 0 & 7 & 6 \\
\infty & \infty & \infty & 4 & 7 & 0 & 9 \\
\infty & \infty & \infty & \infty & 6 & 9 & 0\end{array}\right)$ \\
\hline
\end{tabular}

\section{Iteration $4: 4^{\text {th }}$ row $4^{\text {th }}$ column}

Iteration 4 is the displacement of one level from the $3^{\text {rd }}$ iteration. This $4^{\text {th }}$ iteration matrix is notated $\mathrm{D}(4)$ with a value of $\mathrm{k}=4$. All students in the 4th iteration still identify 30 matrix entries.

$$
\mathrm{D}(4)=\left(\begin{array}{ccc:cccc}
0 & x_{1} & x_{2} & 4 & x_{3} & x_{4} & x_{5} \\
x_{6} & 0 & x_{7} & 9 & x_{8} & x_{9} & x_{10} \\
x_{11} & x_{12} & 0 & 12 & x_{13} & x_{14} & x_{15} \\
\hdashline 4 & 9 & 12 & 0 & 5 & x_{18} & - \\
\hdashline x_{16} & x_{17} & x_{18} & 5 & 0 & x_{19} & x_{20} \\
x_{21} & x_{22} & x_{23} & 4 & x_{24} & 0 & x_{25} \\
x_{26} & x_{27} & x_{28} & \infty_{1} & x_{29} & x_{30} & 0
\end{array}\right)
$$

The procedure for identifying all $\mathrm{x}$ values remains the same as in the previous iteration and only differs for the value $\mathrm{k}=4$. Their calculations on $\mathrm{x}$ use the formula $x_{\mathrm{n}}=\min \left(\mathrm{a}_{\mathrm{ij}}, \mathrm{a}_{\mathrm{ik}}+\mathrm{a}_{\mathrm{kj}}\right)$ where $\mathrm{k}=4$ so $\mathrm{x}_{1}=\min \left(\mathrm{a}_{12}, \mathrm{a}_{14}+\mathrm{a}_{42}\right)=\min (5,4+9)=5, \mathrm{x}_{2}=\min \left(\mathrm{a}_{13}, \mathrm{a}_{14}+\mathrm{a}_{43}\right)=\min (4,8+12)=4$, and so on. The Result of matrix iteration are shown in Table 4. 
Table 4

Comparison of the Value Identification Result D(4)

\begin{tabular}{c} 
Identification result D(4) by MF, NY \\
\& NM \\
\hline $\mathrm{D}(4)=\left(\begin{array}{ccccccc}0 & 5 & 8 & 4 & 9 & 8 & \infty \\
5 & 0 & 13 & 9 & 12 & 13 & \infty \\
8 & 13 & 0 & 12 & 10 & 16 & \infty \\
4 & 9 & 12 & 0 & 5 & 4 & \infty \\
9 & 12 & 10 & 5 & 0 & 7 & 6 \\
8 & 13 & 16 & 4 & 7 & 0 & 9 \\
\infty & \infty & \infty & \infty & 6 & 9 & 0\end{array}\right) \quad \quad \mathrm{D}(4)=\left(\begin{array}{ccccccc}0 & 5 & 8 & 4 & \infty & \infty & \infty \\
5 & 0 & 13 & \infty & 12 & \infty & \infty \\
8 & 13 & 0 & \infty & 10 & \infty & \infty \\
4 & \infty & \infty & 0 & 5 & 4 & \infty \\
\infty & 12 & 10 & 5 & 0 & \infty & 6 \\
\infty & \infty & \infty & 4 & 7 & 0 & 9 \\
\infty & \infty & \infty & \infty & 6 & 9 & 0\end{array}\right)$ \\
\hline
\end{tabular}

\section{Iteration 5: $5^{\text {th }}$ row $5^{\text {th }}$ column}

Iteration 5 is the displacement of one level from the $4^{\text {th }}$ iteration. The $5^{\text {th }}$ iteration matrix is notated $\mathrm{D}(5)$ with a value of $\mathrm{k}=5$. All students in the 5th iteration still identify 30 matrix entries.

$$
\mathrm{D}(5)=\left(\begin{array}{cccc:c:cc}
0 & x_{1} & x_{2} & x_{3} & 9 & x_{4} & x_{5} \\
x_{6} & 0 & x_{7} & x_{8} & 12 & x_{9} & x_{10} \\
x_{11} & x_{12} & 0 & x_{13} & 10 & x_{14} & x_{15} \\
x_{16} & x_{17} & x_{18} & 0 & 5 & x_{19} & x_{20} \\
\hdashline 9 & 12 & 10 & 5 & 0 & 7 \\
\hdashline x_{21} & x_{22} & x_{23} & x_{24} & 7 & 0 & x_{25} \\
x_{26} & x_{27} & x_{28} & x_{29} & 6 & x_{30} & 0
\end{array}\right)
$$

They use determining formula $\mathrm{x}$ with $x_{\mathrm{n}}=\min \left(\mathrm{a}_{\mathrm{ij}}, \mathrm{a}_{\mathrm{ik}}+\mathrm{a}_{\mathrm{kj}}\right)$ dimana $\mathrm{k}=5$ So $\mathrm{x}_{1}=\min \left(\mathrm{a}_{12}, \mathrm{a}_{15}+\mathrm{a}_{52}\right)=$ $\min (5,9+12)=5, x_{2}=\min \left(a_{13}, a_{15}+a_{53}\right)=\min (8,9+10)=8$, and so on. The Result of matrix iteration are shown in Table 5.

Table 5

Comparison of the Value Identification Result D(5)

\begin{tabular}{c} 
Identification result D(5) by MF, NY \\
\& NM \\
\hline $\mathrm{D}(5)=\left(\begin{array}{ccccccc}0 & 5 & 8 & 4 & 9 & 8 & 15 \\
5 & 0 & 13 & 9 & 12 & 13 & 18 \\
8 & 13 & 0 & 12 & 10 & 16 & 16 \\
4 & 9 & 12 & 0 & 5 & 4 & 11 \\
9 & 12 & 10 & 5 & 0 & 7 & 6 \\
8 & 13 & 16 & 4 & 7 & 0 & 9 \\
15 & 18 & 16 & 11 & 6 & 9 & 0\end{array}\right) \quad$ Identification result D(5) by SS \\
\hline
\end{tabular}

\section{Iteration 6: $6^{\text {th }}$ row $6^{\text {th }}$ column}

Iteration 6 is the displacement of one level from the $5^{\text {th }}$ iteration. This $6^{\text {th }}$ iteration matrix is notated $\mathrm{D}(6)$ with a value of $\mathrm{k}=6$. All students in the 6 th iteration identify the values $x_{1}, x_{2}, \ldots, x_{30}$. 


$$
\mathrm{D}(6)=\left(\begin{array}{ccccc:c:c}
0 & x_{1} & x_{2} & x_{3} & x_{4} & 8 & x_{5} \\
x_{6} & 0 & x_{7} & x_{8} & x_{9} & 13 & x_{10} \\
x_{11} & x_{12} & 0 & x_{13} & x_{14} & 16_{1} & x_{15} \\
x_{16} & x_{17} & x_{18} & 0 & x_{19} & 4 & x_{20} \\
x_{21} & x_{22} & x_{23} & x_{24} & 0 & 7 & x_{25} \\
\hdashline 8 & 13 & 16 & 4 & 7 & 0 & 9 \\
\hdashline x_{26} & x_{27} & x_{28} & x_{29} & x_{30} & 9 & 0
\end{array}\right)
$$

They use determining formula $x$ with $x_{\mathrm{n}}=\min \left(\mathrm{a}_{\mathrm{ij}}, \mathrm{a}_{\mathrm{ik}}+\mathrm{a}_{\mathrm{kj}}\right)$ where $\mathrm{k}=6$ So $\mathrm{x}_{1}=\min \left(\mathrm{a}_{12}, \mathrm{a}_{16}+\mathrm{a}_{62}\right)=$ $\min (5,8+13)=5, x_{2}=\min \left(a_{13}, a_{16}+a_{63}\right)=\min (8,8+16)=8$, and so on. The Result of matrix iteration are shown in Table 6 .

Table 6

Comparison of the Value Identification Result D(6)

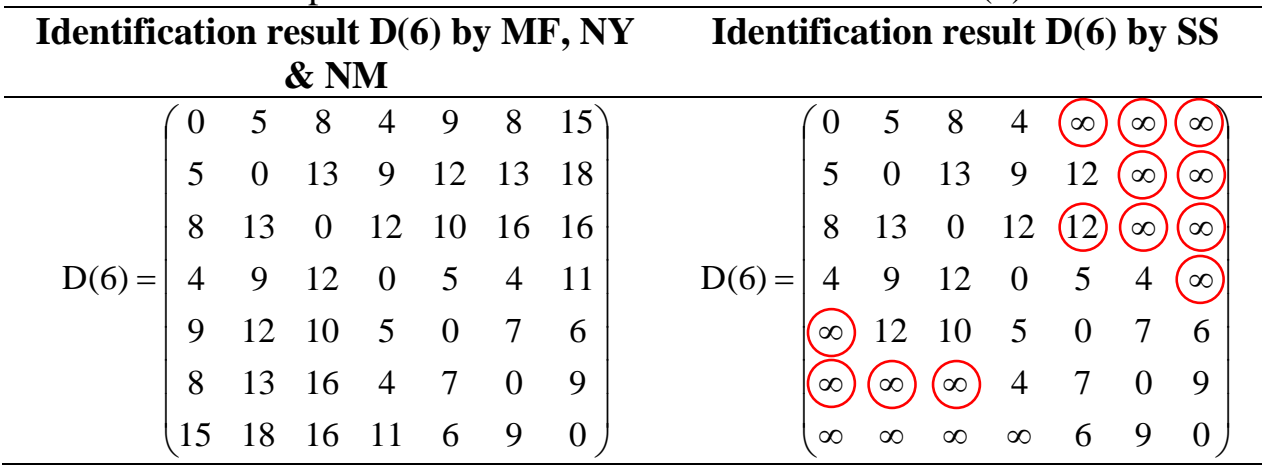

\section{Iteration $7: 7^{\text {th }}$ row $7^{\text {th }}$ column}

Iteration 7 is the displacement of one level from the $6^{\text {th }}$ iteration. This $7^{\text {th }}$ iteration matrix is notated $\mathrm{D}(7)$ with a value of $\mathrm{k}=7$. All students in the 7 th iteration still identify 30 matrix entries.

$$
\mathrm{D}(7)=\left(\begin{array}{cccccc:c}
0 & x_{1} & x_{2} & x_{3} & x_{4} & x_{5} & 15 \\
x_{6} & 0 & x_{7} & x_{8} & x_{9} & x_{10} & 18 \\
x_{11} & x_{12} & 0 & x_{13} & x_{14} & x_{15} & 16 \\
x_{16} & x_{17} & x_{18} & 0 & x_{19} & x_{20} & 11 \\
x_{21} & x_{22} & x_{23} & x_{24} & 0 & x_{25} & 6 \\
x_{26} & x_{27} & x_{28} & x_{29} & x_{30} & 0 & 9 \\
\hdashline 15 & 15 & 16 & 11 \\
\hdashline-15 & 0 & 0 & 0
\end{array}\right.
$$

They use determining formula $\mathrm{x}$ with $x_{\mathrm{n}}=\min \left(\mathrm{a}_{\mathrm{ij}}, \mathrm{a}_{\mathrm{ik}}+\mathrm{a}_{\mathrm{kj}}\right)$ where $\mathrm{k}=7$ So $\mathrm{x}_{1}=\min \left(\mathrm{a}_{12}, \mathrm{a}_{17}+\mathrm{a}_{72}\right)=$ $\min (5,9+12)=5, x_{2}=\min \left(a_{13}, a_{17}+a_{73}\right)=\min (8,9+10)=8$, and so on. The Result of matrix iteration are shown in Table 7.

\section{Study student's thinking process in determining iteration}

The matrix iteration of the Warshall-Floyd algorithm has a strong relationship from the iteration continued. This can be observed in iteration $\mathrm{D}(0)$ produces $\mathrm{D}(1)$, iteration $\mathrm{D}(1)$ produces $\mathrm{D}(2)$, and so on. Therefore, the accuracy and accuracy of the calculation is very necessary for preparing a conclusion. The results of other studies state that most students experience calculation errors and draw conclusions (Putro and Darminto, 2015).

MF, NY, and NM on their mathematical assignments show their meticulous attitude and accuracy in calculating entries in their iteration matrices so that their thinking processes are following thinking 
problems. They can reach the conclusions on their mathematical assignments without obstacles. Meanwhile, SS failed due to inaccurate calculations in the first iteration. With this error, SS cannot find the shortest route for several points, namely (1) points a to e, f, and g, (2) points b, c to f and g, and (3) point $\mathrm{d}$ to $\mathrm{g}$.

Table 7

Comparison of the Value Identification Result D(7)

\begin{tabular}{|c|c|c|c|c|c|c|c|c|c|c|c|c|c|}
\hline \multicolumn{7}{|c|}{$\begin{array}{c}\text { Identification result } \mathrm{D}(7) \text { by } \mathrm{MF}, \mathrm{NY} \\
\text { \& NM }\end{array}$} & \multicolumn{7}{|c|}{ Identification result $\mathrm{D}(7)$ by $\mathrm{SS}$} \\
\hline \multirow{7}{*}{$\mathrm{D}(7)=$} & $\left(\begin{array}{ll}0 & 5\end{array}\right.$ & 8 & 4 & 9 & 8 & 15) & \multirow{7}{*}{$\mathrm{D}(7)=$} & $(0$ & 5 & 8 & 4 & 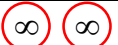 & $\infty$ \\
\hline & 5 & 13 & 9 & 12 & 13 & 18 & & 5 & 0 & 13 & 91 & $12 \infty$ & $\infty$ \\
\hline & 13 & 0 & 12 & 10 & 16 & 16 & & 8 & 13 & 0 & 12 & $10 \infty$ & $\infty$ \\
\hline & 4 & 12 & 0 & 5 & 4 & 11 & & 4 & 9 & 12 & 0 & 54 & $\infty$ \\
\hline & 12 & 10 & 5 & 0 & 7 & 6 & & & 12 & 10 & 5 & 0 & 6 \\
\hline & 13 & 16 & 4 & 7 & 0 & 9 & & & & $\infty$ & & 7 & 9 \\
\hline & $15 \quad 18$ & $8 \quad 16$ & 11 & 6 & 9 & 0 & & & & & $\infty$ & 6 & 0 \\
\hline
\end{tabular}

\section{CONCLUSION AND SUGGESTION}

Giving an example as a form of the facilitator can deliver all students with the level of ability to achieve an understanding of algorithmic work, conceptual understanding and procedural. The matrix iteration process and its entry determination can be followed well even though there are still failures from the research sample. Constraints that cause failure occur due to inaccurate retrieval of matrix entries that trigger calculation errors. This failure was experienced by students with low ability during the first iteration which resulted in a mismatch of the conclusions is made.

\section{REFERENCES}

Attamimi, I., Yahya, W. and Hanfi, Hannats, M. (2017). Analisis Perbandingan Algoritma FloydWarshall dan Dijkstra untuk Menentukan Jalur Terpendek Pada Jaringan Openflow. Jurnal Pengembangan Teknologi Informasi dan Ilmu Komputer (J-PTIIK), 1(12), 1842-1849.

Dermawan, T. S. (2018). Comparison of Dijkstra dan Floyd-Warshall Algorithm to Determine the Best Route of Train. International Journal on Informatics for Development (IJID), 7(2), 8. doi: 10.14421/ijid.2018.07202.

Felipe, A. L., Pham, T. C. and Amouroux, E. (2017). Interdisciplinary Collaborative Teaching in Project-Based Learning Approach. in Integrated Engineering. Sydney: Australasian Association for Engineering Education (AEEE), 1-8.

Husni Al Amin, I.,Lusiana,V.,Hartono,B. (2017). Visualisasi Pencarian Lintasan Terpendek Algoritma Floyd-Warshall dan Dijkstra Menggunakan TEX. in Prosiding SINTAK, 17-23.

Kriswanto, Y. R., Bendi, R. K. and Aliyanto, A. (2014). Penentuan Jarak Terpendek Rute Transmusi dengan Algoritma Floyd-Warshall. Seminar Nasional Teknologi Informasi \& Komunikasi Terapan, 209-216. doi: 10.13140/2.1.2632.6729.

Magzhan, K. and Jani, H. (2013). A Review And Evaluations Of Shortest Path Algorithms. International Journal of Scientific \& Technology Research, 2(6), 99-104. Available at: http://www.ijstr.org/final-print/june2013/A-Review-And-Evaluations-Of-Shortest-PathAlgorithms.pdf.

Marlina, L. (2017). Penerapan Algoritma Dijkstra dan Floyd-Warshall untuk Menentukan Rute Terpendek Tempat Wisata Di Batang. Universitas Negeri Semarang.

Mills, E. J. and Treagust, F. D. (2003). Engineering Education - Is Problem Based Or Project Based Learning The Answer?. Australasian Journal Of Engineering Education, 3(2), 2-16.

Novandi, R. A. D. (2007). Perbandingan Algoritma Dijkstra dan Algoritma Floyd-Warshall dalam 


\section{IJ-MDS International Journal of Multi Discipline Science (IJ-MDS)

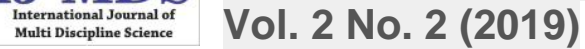 \\ e-ISSN: 2615-1707. Page: 57-65}

Penentuan Lintasan Terpendek ( Single Pair Shortest Path ). Strategi Algoritmik. Available at: http://informatika.stei.itb.ac.id/ rinaldi.munir/Stmik/2006-

2007/Makalah_2007/MakalahSTMIK2007-021.pdf.

Putro, E. P. and Darminto, B. P. (2015). Analisis Kesalahan Dalam Menyelesaikan Soal Ujian Akhir Semester Statistika Dasar Pada Mahasiswa Program Studi Pendidikan Matematika. Ekuivalen, 18(1), 63-68.

Ramadiani., Bukhori, D.,Azainil., and Dengen, N. (2018). Floyd-warshall algorithm to determine the shortest path based on android. IOP Conference Series: Earth and Environmental Science, 144(1). doi: 10.1088/1755-1315/144/1/012019.

Yao, B., Yin, J., Zhou, H., and Wu, Wei. (2016). Path Optimization Algorithms Based on Graph Theory. International Journal of Grid and Distributed Computing, 9(6), 137-148. 